University of Michigan Law School

University of Michigan Law School Scholarship Repository

1910

\title{
Fright without Physical Impact but Resulting in Physical Injury
}

Joseph H. Drake

University of Michigan Law School

Available at: https://repository.law.umich.edu/articles/1608

Follow this and additional works at: https://repository.law.umich.edu/articles

Part of the Law and Psychology Commons, and the Torts Commons

\section{Recommended Citation}

Drake, Joseph H. "Fright without Physical Impact but Resulting in Physical Injury." Mich. L. Rev. 8 (1910): 44-6.

This Response or Comment is brought to you for free and open access by the Faculty Scholarship at University of Michigan Law School Scholarship Repository. It has been accepted for inclusion in Articles by an authorized administrator of University of Michigan Law School Scholarship Repository. For more information, please contact mlaw.repository@umich.edu. 
Frught Without Physical Impact buy Resulting in Physical Injuri: -The recent Maryland case of Green v. T. A. Shoemaker \& Co., reported in 73 Atlantic Reporter, 688, (June, 1909) puts this jurisdiction squarely on the side of those courts that do allow recovery for fright alone, if physical injury is caused thereby. The court confesses that "the numerical weight of authority supports the general rule that there can be no recovery for nervous affections unaccompanied by contemporaneous physical injury," but nevertheless holds firmly with the minority of the courts to the view that there are exceptions to this rule and that this case falls within the exceptions.

The facts of the present case are fortunately so clearly defined as to simplify materially the reasoning of the court. The plaintiff, a young married woman, of sound health, lived in a neighborhood where extensive excavations had been undertaken by the defendant. The repeated explosions of dynamite, used by the defendant in blasting operations, threw stones and dirt on the dwelling of the plaintiff and kept her for a considerable period in a state of nervous terror, though none of the debris actually struck her. As a result of this fright she developed nervous ptostration which her attending physician attributed to the shock of the blasting. 
The courts which have denied recovery on similar states of facts have ustually offered one or more of three different reasons for their decisions. (I) That fright alone may not be a cause of action because, if such a doctrine were once established, it would, in the words of the New York court, "result in a flood of litigation in cases where the injury complained of nay" be easily feigned." Mitchell v. Rochester Ry. Co., I5I N. Y. IIo. (2) That it can not be easily shown that the fright is the proximate cause of the injury alleged. Cf. Ward v. West Jersey etc. Ry. Co., 65 N. J. L. 385. "Physical suffering is not the probable or natural consequence of fright in the case of a person of ordinary physical or mental vigor." (3) A corollary of (2), if fright alone does not warrant recovery, the consequences of fright would not do so. Cf. 3 L. R. A. (N. S.) 50, Note.

That the argument from expediency, for denying recovery for fright unaccompanied by contemporancous physical injury, is unsatisfactory, evien to some of the courts that still uphold the rule, is shown by the use made of this so-called "physical impact theory" to justify a recovery. In the case of Homans v. Boston Elezated Ry. Co., I80 Mass. 456 (1902), Chief Justice HoLMrs says: "When there has been a battery and the nervous shock results from the same wrongful management as the battery, it is $* * *$ impracticable to go further and to inquire whether the shock comes through the battery or along with it." A recent decision of the New Jersey court, Porter v. D. L. \& W. Ry. Co., 73 N. J. L. 405 (Ig06), says that "The proof by the plaintiff was that she was hit on the neck by something and that dust from the falling debris went into her eyes. Proof of cither of these injuries would take the case out of the rule as to non-recovery for fright alone. *** If she received physical injuries, all the resultant effects to her system, due to the accident are recoverable." The Massachusetts court seems also to ignore the necessity of proof of proximate cause. In the Homans case, just cited, it was called to the attention of the court that the effect of the shock of fright was one influence in producing the resultant nervous trouble and the blow was another, and that recovery should be allowed only for the proximate result of the physical impact and not for the result of the shock. The answer of the court to this was, "further refining [in the application of the Masshchusetts Rule] would be wrong."

The expediency argument proceeds upon the theory that nervous injurics are often imaginary rather than real and it is almost impossible to distinguish the one from the other, but our leading case well snys that a nervous injury resulting from physical impact is quite as likely to be imagined or feigned as one resulting from fright without impact, and the former is quite as capable of simulation as the latter.

The answer to the third objection above cited is well given by Sedgwick in his Eirements of LAw of Damiages, Second Ed., p. II4, where he says that the cause of action is the negligence coupled with the material damage, the nerrous shock being the link that connects the two."

The court in the principal case concludes that the rigid rule requiring actual contemporaneous physical inpact producing physical injury can not be applied, and the case should have gone to the jury on the question as to 
whether the injury to the plaintiff's health was a reasonable and natural consequence of the fright.

This case again calls attention to the curious divergence of the courts in their allowance of recovery for the mental suffering caused by sorrow and that form of mental disturbance produced by fright. The Maryland court says that "it may be considered as settled that mere fright without any physical injury resulting therefrom can not form the basis of a cause of action." But recovery is allowed for sorrow alone by a number of courts, following the lead of the Texas court in So Relle v. W. U. Tel. Co., 55 Tex. 308. Cf. Michignn Law Review, Vol. 4, p. 244, and cases there cited. The question naturally arises, what is the reason for this distinction? The California court in the case of Sloane v. S. Cal. Ry. Co., III.Cal. 668, attempted to answer the question by saying that "a nervous shock or paroxysm or a disturbance of the nervous system [caused by fright] is distinct from mental anguish and falls within the physiological rather than. the psychological branch of the human organism. This seems to be a distinction without a difference for it gives us no means of determining what is physiological as distinguished from psychological. In what way is insomnia, for example, produced by a serious fright different from the insomnia produced by deep sorrow, except that the fright is usually of short duration and the sorrow likely to be continuous? It seems not unlikely that the real reason that the courts have had for allowing recovery for sorrow alone and denying it for fright alone rests upon the same argument that has led most of our courts to deny recovery for mental anguish of any sort; namely, the difficulty of proof. It is plainly within the experience of the average person [the juryman] that keen suffering would almost inevitably result to a father by being kept away from the bedside of his dying child, though there might be no - manifest marks of that sorrow. On the other hand, in the cases where fright is alleged as a variety of mental suffering endured, it is by no means so plain that the suffering actually has occurred unless some physical result therefrom is shown.

The leading case brings one more court over to the minority that allows recovery for fright as a form of mental anguish, if the proof thereof is plain, and we may well hazard the conjecture that if the courts have presented to them cases in which the causal relation is evident between the injuries complained of and the mental anguish produced by the negligent act, the tendency will be for them to range themselves on the side of those courts now in the minority, unless they should feel compelled by their own previous decisions to say, as did the Pennsylvania court in the Huston case, supra, that the question "is settled for this state and no longer open for discussion." 